\title{
KEDUDUKAN ANAK PEREMPUAN MENURUT HUKUM WARIS ADAT SUKU PAKPAK (Studi Penelitian di Kecamatan Sitellu Tali Urang Jehe Kabupaten Pakpak Bharat Provinsi Sumatera Utara)
}

\author{
${ }^{1}$ Wendi Arismunandar Sagala. ${ }^{2}$ Jamaluddin, ${ }^{2}$ Manfarisyah \\ Co. Author :jamaluddin@unimal.ac.id \\ ${ }^{1}$ Mahasiswa Fakultas Hukum Universitas Malikussaleh \\ ${ }^{2}$ Dosen Fakultas Hukum Universitas Malikussaleh
}

\begin{abstract}
This study aims to determine the position of girls in the inheritance system of the Pakpak Tribe and to find The actions of the daughters of the Pakpak Tribe in Sitellu Tali Urang Jehe district, Pakpak Bharat regency when the division of inheritance property is done using the Pakpak Customary inheritance law. The patrilineal system is an inheritance system that passes down the inheritance from the heir to the offspring or son, so it does not mean that the wife and daughter are heirs when the husband or father / father dies. This research method is juridical empirical or field (feild research) with a sociological juridical approach. Based on this research, if using Pakpak's customary rules, girls do not get inherited assets, but girls can get inherited assets, but only movable objects such as money, livestock, and gold. Girls are also entitled to other objects such as machetes, mats, and used clothes. Girls in the Pakpak traditional inheritance system may receive inheritance such as land, houses, or other assets if there is an agreement between all the heirs. Until now, there are no girls in Sitellu Tali Urang Jehe District who have disputed this inheritance with traditional leaders.
\end{abstract}




\section{PENDAHULUAN}

Indonesia sebagai negara hukum, maka yang merupakan hasil dari keadaan sekarang ini adalah negara mengelola setiap ruang kehidupan individu melalui pedoman sebagai hasil hukum yang sebenarnya. Hukum di Indonesia berubah secara luas karena dipengaruhi oleh keadaan budaya majemuk. Pada titik itu, masyarakat majemuk sendiri merupakan istilah yang memiliki makna yang sama dengan istilah pluralistik atau budaya majemuk. Biasanya hal ini diartikan sebagai masyarakat yang terdiri dari berbagai suku bangsa atau masyarakat yang berbhinneka. ${ }^{1}$

G. A. Theodorson menjelaskan bahwa pluralisme atau pluralisme sosial adalah keragaman masyarakat, kebangsaan, dan kelompok minoritas lainnya yang menjaga kepribadiannya dalam iklim sosial. Selain itu, F. Goult juga mengutarakan pentingnya pluralisme dalam sebuah referensi kata yang berjudul Dictionary of Modern Science Human Science, yaitu : ${ }^{2}$

1. Dalam iklim sosial yang beragam, tidak ada penyesuaian terhadap lingkungan dan hasilhasilnya.

2. Doktrin (biasa disebut ragam sosial) yang menyatakan bahwa pertemuan lokal akan menguntungkan jika dibingkai dari beberapa pertemuan etnis yang saling mengandalkan dalam memperluas derajat kemandirian. Kemungkinan bahwa kerangka sosio-sosial yang sangat besar dapat dikonseptualisasikan sebagai kumpulan sub-kerangka yang bergantung meskipun pada kenyataannya sering mengatur dirinya sendiri

Keragaman digambarkan oleh masyarakat yang berbeda, untuk situasi ini keragaman kebangsaan, agama, masyarakat, adat istiadat, dll. Dengan tujuan agar undang-undang yang menyelenggarakannya dapat mengatur keragaman tersebut.. Hukum di Indonesia berbentuk tertulis dan tidak tertulis, yang pembentukannya mengikuti sejarah dan perkembangan masyarakatnya. Hukum yang tidak tertulis yang merupakan hukum yang tercipta dari kehidupan masyarakat yang menjadi kebiasaan atau adat di Indonesia, sehingga hukum yang tidak tertulis atau hukum adat tersebut disebut sebagai Living law yaitu hukum yang timbul, berlaku, dan hukum yang hidup di masyarakat tersebut. ${ }^{3}$

Hukum adat di Indonesia antara satu daerah dengan daerah lainnya itu berbeda-beda, ialah tergantung pada kehidupan sosial dan kebudayaannya. Begitu pula dengan hukum yang relevan secara keseluruhan, hukum standar sebagai akibatnya pada suatu ruang juga mengarahkan seluruh bagian dari keberadaan individu pribumi, seperti hubungan adat, perceraian, lewat jasa, dinamika baku, warisan adat, pertukaran tanah yang dipimpin oleh daerah setempat, adat istiadat, dll. tanah yang dilatih oleh kelompok masyarakat asli, dll. Salah satu kegiatan penting dari beberapa hal tersebut diatas yang hingga saat ini pelaksanaannya masih seringkali menimbulkan permasalahan dalam masyarakat itu sendiri yaitu, mengenai pelaksanaan pewarisan adat. Kita menyadari bahwa tradisi di setiap daerah itu unik, sehingga pelaksanaan warisan standar di berbagai daerah di Indonesia sungguh luar biasa. Misalnya, masyarakat asli Minangkabau berpegang teguh pada kerangka warisan Matrilineal, yaitu kerangka warisan yang diambil dari garis ibu, sedangkan pada ruang-ruang tertentu, misalnya marga Batak dan Sentani di Jayapura, kerangka warisan Patrilineal. ${ }^{4}$

Pewarisan hanya dapat dilakukan setelah kematian seseorang. Kemudian dengan meninggalnya seseorang tersebut maka kekayaan- kekayaanya akan beralih keorang lain yang

\footnotetext{
${ }^{1}$ Soerjono Soekanto, 2011, Hukum Adat Indonesia, Jakarta: Rajawali Pers, hlm. 12

${ }^{2}$ Ibid.

${ }^{3}$ Ibid., hlm. 69

${ }^{4}$ Erman Suparman, 2005, Hukum Waris Indonesia, Bandung: PT Refika Aditama, hlm. 44, 56
} Jurnal Ilmiah Mahasiswa FH: Volume IV Nomor 2 (April, 2021) | 110 
ditinggalkannya. Untuk itu diperlukan adanya aturan-aturan yang mengatur hubungan antara orang yang telah meninggal dengan harta kekayaannya dan dengan orang yang akan menerima peralihan harta kekayaan tersebut. Aturan-aturan yang mengatur mengenai hubungan tersebut dikenal dengan hukum waris adat. Hukum warisan standar adalah hukum standar yang memuat garis-garis pengaturan berkenaan dengan kerangka dan standar hukum warisan, tentang warisan, penerima dan penerima manfaat serta bagaimana kendali dan tanggung jawab atas warisan dipindahkan dari pemberi ke penerima. ${ }^{5}$ ditarik menurut garis bapak, dimana kedudukan pria lebih menonjol pengaruhnya dari kedudukan wanita. Sistem patrilineal yaitu sistem kewarisan yang menurunkan harta warisan dari pewaris kepada keturunan atau anak laki-lakinya, jadi tidak di maksudkan isteri dan anak perempuan sebagai ahli waris ketika suami atau ayah/bapak meninggal. Kemudian dalam hukum waris adat tersebut, di beberapa daerah berlaku sistem pewarisan berdasarkan garis keturunan orang tua (ayah dan/atau ibu). Demikian pula halnya pada pewarisan di masyarakat adat Kabupaten Pakpak Bharat, khususnya pada Suku Pakpak. Pewarisan dalam suku Pakpak menganut sistem Patrilineal sehingga dengan sistem ini kedudukan pria lebih besar pengaruhnya dari pada kedudukan wanita. Sistem patrilineal ialah sistem kewarisan yang menurunkan harta warisan dari pewaris kepada keturunan atau anak laki-lakinya, jadi tidak di maksudkan isteri dan anak perempuan sebagai ahli waris ketika suami atau ayah/bapak meninggal.

Sistem kekerabatan pada masyarakat patrilineal pada umumnya ini juga berpengaruh pada kedudukan janda dan anak perempuan. kedudukan janda menurut adat bertitik tolak pada aturan bahwa perempuan sebagai orang asing sehingga tidak berhak mewaris, namun selaku isteri berhak untuk memiliki harta yang diperoleh selamanya karena ikatan perkawinan (harta bersama). Oleh sebab itulah, janda pada masyarakat patrilineal terdapat suatu ketentuan, yaitu apabila janda diintegrasikan ke dalam kerabat suaminya, ia dapat menetap di sana dan mendapatkan nafkahnya. ${ }^{6}$

Meskipun setelah keluarnya yurisprudensi tetap di indonesia Keputusan MA Republik Indonesia tahun 1961 Nomor 179/Sip/1961 yang menegaskan bahwa bagian warisan janda dan anak-anak itu sama-sama memiliki hak mendapatkan warisan tanpa mempersoalkan anak itu lakilaki ataupun anak perempuan. Hal ini diperkuat melalui Undang-undang Nomor 1 Tahun 1974 tentang Perkawinan yang mempersepsikan persamaan hak dan kedudukan setiap penduduk Indonesia, baik laki-laki maupun perempuan. Kewarisan adat menurut sistem patrilineal yang hanya mewariskan harta warisan kepada keturunan atau anak laki-lakinya, namun akan menjadi suatu permasalahan kemudian apabila didalam keluarga tersebut memiliki anak perempuan. Hal ini pulalah yang akan penulis bahas lebih lanjut yaitu terkait dengan bagaimana status dan kedudukan anak perempuan dalam sistem kewarisan adat khususnya dalam masyarakat adat Suku Pakpak di Kecamatan Sitellu Tali Urang Jehe Kabupaten Pakpak Bharat Provinsi Sumatera Utara, serta bagaimana proses pelaksanaan pewarisan dengan sistem patrilineal tersebut.

Berdasarkan uraian latar belakang di atas, maka penulis mengangkat permasalahan yang akan dibahas dalam tulisan ini, yaitu Bagaimana kedudukan anak perempuan dalam sistem kewarisan hukum adat Suku Pakpak di Kecamatan Sitellu Tali Urang Jehe Kabupaten Pakpak Bharat. Bagaimana tindakan anak perempuan Suku Pakpak di Kecamatan Sitellu Tali Urang Jehe kabupaten Pakpak Bharat apabila pembagian harta warisan dilakukan menggunakan hukum waris Adat Pakpak.

Adapun tujuan yang ingin dicapai dari penelitian ini berdasarkan rumusan masalah di atas ialah Untuk mengetahui kedudukan anak perempuan dalam sistem kewarisan Suku Pakpak di

\footnotetext{
${ }^{5}$ Hilman Hadikusuma, 2003, Hukum Waris Adat, Bandung: PT Citra Aditya Bakti, hlm. 7

${ }^{6}$ Iman Sudiyat, 1998, Hukum Adat Sketsa Asas, Jogjakarta: Liberty, hlm.166
} 
Kecamatan Sitellu Tali Urang Jehe Kabupaten Pakpak Bharat. Untuk mengetahui tindakan anak perempuan Suku Pakpak di Kecamatan Sitellu Tali Urang Jehe kabupaten Pakpak Bharat apabila pembagian harta warisan dilakukan menggunakan hukum waris Adat Pakpak.

\section{METODE PENELITIAN}

Penulis menggunakan jenis penelitian yuridis empiris atau lapangan (feild research) yang berlokasi di Kecamatan Sitellu Tali Urang Jehe, Kabupaten Pakpak Bharat, Sumatera Utara. Dalam penulisan ini permasalahan utama yang ingin diteliti dalam penelitian ini adalah Kedudukan Anak Perempuan Menurut Hukum Waris Adat Suku Pakpak. Metode pendekatan dalam penelitian ini adalah yuridis sosiologis yaitu data yang didapat lansung dari informan sebagai sumber pertama dengan melalui kegiatan penelitian lapangan dengan teknik wawancara baik terstruktur maupun tidak. Sifat penelitian yang digunakan ialah penelitian deskriptif (deskriptiveresearch) yaitu penelitian yang bertujuan untuk menggambarkan secara tepat sifat-sifat suatu individu, keadaan, gejala atau penyebaran suatu gejala atau frekuensi adanya hubungan tertentu antara suatu gejala dan gejala lain dalam masyarakat. Adapun bentuk dari penelitian ini adalah bentuk preskriptif, preskriptif dilakukan guna memberikan gambaran atau rumusan masalah sesuai dengan keadaan atau fakta yang ada. Dalam menyelesaikan penelitian ini, penulis memilih lokasi penelitian yaitu di Kecamatan Sitellu Tali Urang Jehe Kabupaten Pakpak Bharat pada suku Pakpak di khususkan pada3 (tiga) Desa yaitu Desa Tanjung Meriah, Desa Maholida, dan Desa Kaban Tengah Sitellu Tali Urang Jehe Kabupaten Pakpak Bharat Provinsi Sumatera Utara. Dipilihnya lokasi penelitian ini dengan pertimbangan bahwa daerah tersebut terkait dengan kedudukan anak perempuan dalam hukum waris adat masyarakat tersebut sehingga peneliti dapat dengan mudah memperoleh data dan informasi tentang judul yang peneliti angkat. Populasi dalam penelitian ini adalah pihak-pihak yang terkait dengan penentuan kedudukan anak perempuan sebagai ahli waris menurut hukum waris masyarakat patrilineal dalam suku pakpak di Kecamatan Sitellu Tali Urang Jehe Kabupaten Pakpak Bharat. Sampel dalam penelitian ini dipilih dengan purposive sampling. Yaitu metode pemilihan elemen sampel dengan sengaja, yaitu dipilih orang orang yang dianggap dapat memberikan informasi yang jelas tentang masalah yang dibahas dan diperkirakan mampu mewakili populasi penelitian yang terdiri dari informan dan responden. ${ }^{7}$

\section{HASIL PENELITIAN DAN PEMBAHASAN}

\section{Keadaan Geografis}

Sebagaimana telah diuraikan sebelumnya bahwa kegiatan penelitian ini dilaksanakan di 3 (tiga) Desa yang ada di Kecamatan Sitellu Tali Urang Jehe Kabupaten Pakpak Bharat sebagai daerah yang menjadi Subyek penelitian ini, Adapun ketiga desa tersebut ialah Desa Tanjung Meriah, Desa Kaban Tengah dan Desa Maholida Kabupaten Pakpak Bharat adalah salah satu kabupaten yang ada di Sumatera Utara. Kabupaten ini dibentuk pada tanggal 25 Februari 2003, beribukotakan Kota Salak. Kabupaten ini berdiri sebagai hasil pemekaran dari Kabupaten Dairi. Kini Kabupaten Pakpak Bharat memiliki 8 kecamatan, yaitu Kecamatan Salak, Kecamatan Sitellu Tali Urang Jehe, Kecamatan Pangindar, Kecamatan Sitellu Tari Urang Julu, Kecamatan Pergetteng-getteng Sengkut, Kecamatan Kerajaan, Kecamatan Tinada, dan Kecamatan Siempat Rube.

Kecamatan Sitellu Tali urang Jehe memiliki 10 Desa yaitu Simberuna, Maholida, Tanjung Meriah, Bandar Baru, Perjaga, Kaban Tengah, Perolihen, Mbinalun, Malum dan Tanjung Mulia.

\footnotetext{
${ }^{7}$ J. Supranto, Metode Penelitian HukumDan Statistik. PT. Tineka Cipta, Jakarta, 2003, hlm,30.
} 
Kecamatan Sitellu Tali Urang Jehe memiliki posisi yang sangat strategis karena merupakan Daerah Lintasan Dari Jalan Negara Propinsi NAD dan Propinsi SUMUT. Kecamatan Sitellu Tali Urang Jehe memiliki wilayah dengan luas $473,62 \mathrm{Km}^{2}$. Kecamatan Sitellu Tali Urang Jehe memiliki Batas-batas wilayah sebagai berikut

1. Sebelah Utara: Kecamatan Silima Pungga-Pungga, Kecamatan Lae Parira dan Kecamatan Sidikalang Kabupaten Dairi.

2. Sebelah Selatan: Kecamatan Salak dan Kecamatan Kerajaan Kabupaten Pakpak Bharat

3. Sebelah Barat: Kabupaten Aceh Singkil Provinsi Aceh

4. Sebelah Timur: Kecamatan Kerajaan Kabupaten Pakpak Bharat.

\section{Keadaan Penduduk}

Pola kehidupan penduduk / masyarakat yang berdomisili di Kecamatan Sitellu Tali Urang Jehe pada umumnya terikat pada adat istiadat setempat yaitu adat Pakpak. Hukum adat yang berlaku adalah hukum adat Pakpak, dan berlaku di semua Desa /Kelurahan yang ada di Kabupaten Pakpak Bharat. Mata pencaharian utama penduduk di Sitellu Tali Urang Jehe adalah bertani kemudian ada pula sebagian kecil yang berprofesi sebagai pedagang, peternak dan pegawai negeri. Mereka yang melakukan pekerjaan berladang kebanyakan ladang mereka ditanami jenis Padi, Jagung, Kelapa, Pinang, Durian, Langsat, Pete, Jengkol, Nangka dan Pisang.

\section{Gambaran Umum Masyarakat Adat Suku Pakpak}

Suku Pakpak merupakan salah satu suku di Indonesia yang dapat ditemui di pulau Sumatera Indonesia yakni tersebar di beberapa wilayah kabupaten/kota di Sumatra Utara dan Aceh, antara lain di Kabupaten Dairi, Kabupaten Pakpak Bharat, Kabupaten Humbang Hasundutan, Tapanuli Tengah (Sumatra Utara), Kabupaten Aceh Singkil dan Kota Subulussalam (Aceh). Suku Pakpak terdiri atas 5 subsuku, dalam istilah setempat sering disebut dengan istilah Pakpak Silima Suak yang terdiri dari:

a) Pakpak Klasen, subsuku ini umumnya mendiami wilayah Parlilitan yang berada di Kabupaten Humbang Hasundutan dan wilayah Manduamas yang merupakan bagian dari kabupaten Tapanuli Tengah.

b) Pakpak Simsim, subsuku ini mendiami wilayah kabupaten Pakpak Bharat.

c) Pakpak Boang, pada umumnya sub suku ini bertempat tinggal di Kota Subulussalam dan Kabupaten Aceh Singkil yang terletak di Provinsi Aceh. Suku Pakpak Boang ini banyak disalah pahami sebagai suku Singkil.

d) Pakpak Pegagan, bermukim di Sumbul dan sekitarnya di Kabupaten Dairi.

e) Pakpak Keppas, bermukim di kota Sidikalang dan sekitarnya di Kabupaten Dairi.

Pada umumnya masyarakat adat Pakpak di Pakpak Bharat bermata pencaharian sebagai petani karena tanah di Pakpak Bharat sangatlah Subur dan Luas. Sistem bercocok tanam yang mereka terapkan masih bersifat tradisional, bahkan masih ada yang melakukan sistem berlandang berpindah-pindah dimana lahan dibersihkan, pepohonan ditebang dan dibakar kemudian ditanami dengan tanaman muda seperti Padi dan tanaman Tua seperti Durian lalu setelah padi dipanen kemudian mereka berpindah ke tempat lain. Selain itu ada pula diantara mereka yang bermata pencaharian sebagai pedagang atau ber Kedde dalam bahasa Pakpak, Mata pencaharian lainnya yang digeluti saat ini adalah PNS dan anggota TNI/Polri.

\section{Bahasa}

Jurnal Ilmiah Mahasiswa FH: Volume IV Nomor 2 (April, 2021) | 113 
Bahasa yang dipergunakan oleh penduduk Pakpak Bharat khususnya penduduk Kecamatan Sitellu Tali Urang Jehe dalam kehidupan sehari-hari adalah bahasa Pakpak.

\section{Kedudukan Anak Perempuan Dalam Sistem Kewarisan Suku Pakpak di Sitellu Tali Urang Jehe Kabupaten Pakpak Bharat \\ Kecamatan}

Berbicara tentang Kedudukan berarti akan membahas tentang tingkatan ,martabat keadaan seseorang, status keadaan, badan atau negara. Jaringan sah Indonesia jika dilihat dari sudut pandang keluarga adalah unik, setiap iklim standar memiliki kerangka keluarga alternatif. Dengan cara yang sama, situasi pria dan wanita muda pada tingkat dasar yang unik. Dalam sistem waris adat pakpak di Kecamatan Sitellu Tali Urang Jehe Kabupaten Pakpak Bharat kedudukan anak Perempuan sangatlah jauh berbeda dengan kedudukan anak laki-laki. Lister Berutu Seorang Dosen Antropologi Universitas Sumatera Utara yang merupakan Tokoh Pakpak yang sangat dikenal di kabupaten pakpak Bharat menjelaskan Jika memakai Aturan adat Pakpak maka anak perempuan tidaklah mendapat harta warisan, namun Anak Perempuan Boleh mendapat Harta Warisan tetapi hanya barang bergerak seperti Uang, Ternak, dan Emas saja. ${ }^{8}$

Pinayungen seorang Tokoh adat desa Kaban Tengah menjelaskan kedudukan anak perempuan bukanlah merupakan ahli waris sehingga anak perempuan dalam hukum adat Pakpak tidak mendapatkan harta Warisan, Anak perempuan hanya berhak mendapatkan warisan berupa benda saja seperti Parang, Tikar, Pakaian Bekas Pewaris. ${ }^{9}$

Tumangger sebagai Tokoh adat Desa maholida menjelaskan bahwa Secara adat pakpak Anak Perempuan tidak mendapat harta warisan, namun Anak Perempuan dalam Sistem kewarisan adat Pakpak boleh saja mendapatkan harta warisan seperti tanah, rumah, maupun harta lainnya jika adanya kesepakatan antara semua ahli waris. ${ }^{10}$

Kemudian jika dalam keluarga tersebut tidak memiliki anak laki-laki atau hanya mempunyai anak perempuan, maka yang menjadi ahli Waris anak perempuan pewaris tersebut. ${ }^{11}$ Dimana dapat di simpulkan bahwa pada dasarnya kedudukan anak perempuan dalam suku Pakpak khususnya dalam sistem pewarisan sangatlah lemah dibandingkan dengan kedudukan anak lakilaki. Hal ini disebabkan oleh beberapa hal, yakni :

1. Kedudukan anak laki-laki khususnya anak sulung memiliki kewajiban sebagai penerus tanggung jawab dari orang tuanya untuk memenuhi setiap kebutuhan keluarganya dan merawat serta menafkahi adik-adiknya hingga dewasa.

2. Perempuan akan menikah dan meninggalkan keluarganya atau ikut dengan suaminya yang bermarga lain karena dalam masyarakat adat pakpak anak perempuan diharuskan untuk kawin keluar dari marganya.

3. Anak Perempuan tidak bisa meneruskan marganya kepada anak-anaknya karena marga dari suaminyalah yang akan diberikan kepada anak-anaknya.

4. Anak Laki-laki akan meneruskan marga dari keluarganya kepada anak-anaknya.

Berbicara tentang kewarisan, berarti berbicara mengenai adanya peristiwa penting dalam suatu masyarakat tertentu, yaitu salah seorang dari anggota masyarakat tersebut ada yang meninggal dunia. Apabila orang yang meninggal tersebut memiliki harta kekayaan, maka pesoalannya adalah bukan tentang peristiwa kematian, melainkan harta yang ditinggalkan oleh pewaris.

\footnotetext{
${ }^{8}$ Lister Berutu, Dosen Antropologi Universitas Sumatera Utara, Wawancara 13 November 2020

${ }^{9}$ Pinayungen, Tokoh Adat Desa Kaban Tengah, Wawancara 3 Januari 2021

${ }^{10}$ Tumangger, Tokoh Adat Desa Maholida, Wawancara 24 Januari 2021

${ }^{11}$ Sirsir Padang, Tokoh Adat Desa Tanjung Meriah, Wawancara 26 Januari 2021
} 
Dalam sistem waris adat Pakpak di Kecamatan Sitellu Tali Urang Jehe Kabupaten Pakpak Bharat harta warisan akan dibagikan setelah Pewaris meninggal dunia, akan tetapi harta warisan juga boleh dibagikan sebelum Pewaris meninggal dunia. ${ }^{12}$

Pewarisan menurut hukum adat pada masyarakat adat Pakpak bukan merupakan suatu kesatuan yang dapat dinilai harganya, tetapi merupakan suatu kesatuan yang tidak dapat terbagi atau dapat dibagi menurut jenis dan macamnya, karena dalam pewarisan pada masyarakat adat Pakpak terdapat harta yang tidak dapat dibagikan kepada ahli waris secara pribadi tetapi milik bersama para ahli waris demikian pula sebaliknya dalam adat pakpak ada harta yang tidak dapat dibagi dan diperuntukkan hanya untuk ahli waris tertentu saja. ${ }^{13}$

Masyarakat Pakpak pada umumnya berpegang teguh pada kerangka Patrilineal, yaitu kerangka bawaan yang ditarik oleh garis ayah dimana situasi laki-laki lebih mencolok daripada situasi perempuan sebagai penerima manfaat. Hal ini menunjukkan adanya perbedaan kedudukan dan hak mewaris yang sangat menonjol dimana secara adat telah ditetapkan bahwa anak lakilakilah yang memiliki hak menjadi ahli waris, sedangkan anak perempuan tidak memiliki hak menjadi ahli waris atas harta warisan orang tuanya.

Berdasarkan hukum adat Suku Pakpak di Kecamatan Sitellu Tali Urang Jehe dalam pembagian harta warisan sebaiknya dihadiri oleh Struktur Sosial atau dalam bahasa Pakpak disebut "Sulang Silima". Sulang silima terdiri dari lima unsur yakni: 1. Sinina tertua (Perisang-isang = keturunan atau generasi tertua) 2. Sinina penengah (Pertulan tengah $=$ keturunan atau generasi yang di tengah) 3. Sinina terbungsu (perekur-ekur $=$ keturunan terbungsu) 4. Berru (kerabat penerima gadis) 5. Puang (kerabat pemberi gadis). ${ }^{14}$

Dalam sistem kewarisan adat pakpak mengenal ada beberapa Harta Warisan yang tidak dapat dibagikan kepada ahli waris secara pribadi tetapi milik bersama para ahli waris contohnya seperti Pokok Durian yang sudah disepakati milik bersama ahli waris, apabila musim durian maka para ahli waris akan bergantian memanen buah durian tersebut. Demikian pula sebaliknya dalam adat pakpak ada harta yang tidak dapat dibagi dan diperuntukkan hanya untuk ahli waris tertentu saja seperti Rumah, Jika Pewaris meninggalkan sebuah rumah maka rumah tersebut diperuntukkan hanya untuk Anak Laki-laki Paling Bungsu atau paling muda saja, Apabila pewaris meninggalkan 2 (dua) Rumah maka rumah tersebut akan diberikan untuk anak Laki-Laki Tertua dan Termuda.

\section{Tindakan anak perempuan Suku Pakpak di Kecamatan Sitellu Tali Urang Jehe kabupaten Pakpak Bharat apabila pembagian harta warisan dilakukan menggunakan hukum waris Adat Pakpak}

Masyarakat adat Pakpak adalah masyarakat adat yang memiliki aturan adatnya tersendiri, memiliki beragam aturan adat yang mengatur segala aspek kehidupan masyarakatnya termasuk mengatur waris adat beserta sanksinya apabila ada sengketa adat. Berdasarkan aturan adat pakpak apabila ada sengketa adat di wilayah tersebut maka bisa diselesaikan secara adat dengan melapor kepada tokoh adat setempat untuk ditindak lanjuti secara adat Pakpak. ${ }^{15}$

Anak Perempuan di kecamatan Sitellu Tali Urang Jehe Kabupaten Pakpak Bharat hingga saat ini masih mendapatkan warisan dengan sistem kewarisan secara adat Pakpak. Artinya anak perempuan di kecamatan tersebut ada yang tidak mendapat harta warisan, ada yang hanya mendapat warisan berupa benda bergerak saja, dan ada juga yang mendapatkan warisan.

\footnotetext{
${ }^{12}$ Lister Berutu, Dosen Antropologi Universitas Sumatera Utara, Wawancara 13 November 2020

${ }^{13}$ Sirsir Padang, Tokoh Adat Desa Tanjung Meriah, Wawancara 26 Januari 2021

${ }^{14}$ Lister Berutu, Dosen Antropologi Universitas Sumatera Utara, Wawancara 13 November 2020

${ }^{15}$ Lister Berutu, Dosen Antropologi Universitas Sumatera Utara, Wawancara 13 November 2020
} 
Maharaja seorang anak perempuan berumur 60 tahun di Desa Tanjung Meriah yang tidak mendapatkan harta warisan memilih untuk menerima pembagian harta warisan dengan sistem Waris adat pakpak dan tidak menyengketakan harta warisan karena berpendapat bahwa apabila disengketakan maka hubungan keluarga pastinya akan berpengaruh buruk kedepannya. Jika harta Warisan ini disengketakan maka kedepan keluarga akan menjadi tidak harmonis antara sesama saudara, bahkan imbas ketidakharmonisan sesama saudara bisa sampai ke anak bahkan sampai cucu-cucu dikemudian hari. ${ }^{16}$

Nanduan seorang anak Perempuan berusia 46 tahun yang berprofesi sebagai petani di Desa Kaban Tengah yang tidak mendapat harta warisan memilih untuk menerima pembagian harta warisan dilakukan dengan sistem waris adat pakpak walaupun tidak ikhlas dan tidak menyengketakan masalah harta warisan karena aturan adat dari dulu seperti itu sehingga malas menentangnya dan menganggap hal tersebut sudah hal yang biasa. ${ }^{17}$

Nurhaty Solin warga Desa Maholida berumur 50 Tahun seorang anak perempuan yang berprofesi sebagai petani mendapatkan Warisan berupa Tanah seluas $300 \mathrm{~m}^{2}$ tidak menyengketakan warisan tersebut karena sudah mendapat warisan walaupun sangat jauh perbedaan bagiannya dengan saudara laki-laki. ${ }^{18}$

Tokoh adat Desa Maholida berpendapat bahwa anak perempuan tidak menyengketakan masalah harta warisan dengan sistem adat Pakpak karena bila disengketakan maka hasil tetap akan sama, tokoh adat hanya akan menjelaskan bahwa anak perempuan memang pada dasarnya tidak memiliki hak mendapatkan warisan, apalagi warisan berupa tanah dan rumah itu mutlak hak warisan anak laki-laki. Namun demikian anak perempuan di desa Maholida Kecamatan Sitellu Tali urang Jehe sangat mengharapkan pengertian dari saudara laki-laki untuk memberikan harta warisan kepada saudara perempuannya. ${ }^{19}$

Sampai saat ini belum ada anak perempuan di Kecamatan Sitellu Tali Urang Jehe yang menyengketakan warisan ini kepada tokoh adat, Hal ini disebabkan oleh beberapa Faktor yaitu :

1. Apabila disengketakan maka hubungan keluarga pastinya akan berpengaruh buruk kedepannya.

2. Karena sudah aturan adat dari dulu seperti itu sehingga masyarakat malas menentangnya.

3. Kalaupun disengketakan aturannya tetap sama tetap menggunakan aturan waris adat Pakpak

4. Anak Perempuan mengharapkan pengertian saudara laki-lakinya

Pembagian Harta Warisan di Kecamatan Sitellu Tali Urang Jehe Kabupaten Pakpak Bharat seharusnya disesuaikan dengan aturan agama yang dianut oleh masing-masing masyarakat adat atau disesuaikan dengan hukum waris Perdata yang berlaku di Indonesia karena anak perempuan juga berhak mendapatkan harta warisan. Seperti yang diatur oleh hukum waris Islam, pada prinsip pembagiannya bahwa anak laki-laki menerima bagian yang lebih besar daripada perempuan, bila hanya sato orang anak perempuan maka ia mendapat setengah bagian, bila terdapat dua orang anak perempuan atau lebih maka mereka bersama-sama mendapat dua pertiga bagian, dan apabila anak perempuan bersama-sama dengan anak laki-laki, maka bagian anak lakilaki adalah dua berbanding satu dengan anak perempuan. Pada Intinya Anak perempuan memiliki hak menerima warisan walaupun bagiannya tidak sama dengan anak laki-laki.

\section{KESIMPULAN}

\footnotetext{
${ }^{16}$ Maharaja, Anak Perempuan di Desa Tanjung Meriah, Wawancara 25 November 2020

${ }^{17}$ Nanduan, Anak Perempuan di Desa Kaban Tengah, Wawancara 25 November 2020

18 Nurhaty Solin, anak Perempuan Desa Maholida, Wawancara 17 Januari 2021

${ }^{19}$ Tumangger, Tokoh Adat Desa Maholida, Wawancara 24 Januari 2021
} 
Berdasarkan pemaparan hasil penelitian dan pembahasan, adapun kesimpulan yang dapat diambil, yaitu Kedudukan anak perempuan dalam sistem pewarisan pada masyarakat adat Pakpak khususnya di Kecamatan Sitellu Tali Urang Jehe bukanlah bagian dari ahli waris, anak perempuan hanya berhak memperoleh harta berupa benda bergerak saja seperti uang, emas, pakaian saja. Sistem kewarisan adat pakpak menganut sistem Patrilineal sehingga hanya memberikan warisan kepada anak laki-laki saja. Tindakan Anak perempuan di Kecamatan Sitellu Tali Urang Jehe tidak ada yang menyengketakan aturan adat Pakpak tersebut karena aturan tersebut sudah berlaku turuntemurun, anak perempuan tidak ingin hubungan antar saudara menjadi rusak, anak perempuan mengharapkan pengertian dari saudara laki-lakinya, dan apabila disengketakanpun hasilnya akan tetap sama. Anak perempuan di Kecamatan Sitellu Tali Urang Jehe menerima sistem kewarisan adat Pakpak walaupun tidak menerima dengan Ikhlas.

\section{DAFTAR PUSTAKA}

Erman Suparman, 2005, Hukum Waris Indonesia, Bandung: PT Refika Aditama (Buku yang ditulis oleh editor)

Hilman Hadikusuma, 2003, Hukum Waris Adat, Bandung: PT Citra Aditya Bakti (Buku yang ditulis oleh editor)

Iman Sudiyat, 1998, Hukum Adat Sketsa Asas, Jogjakarta: Liberty (Buku yang ditulis oleh editor) Soerjono Soekanto, 2011, Hukum Adat Indonesia, Jakarta: Rajawali Pers (Buku yang ditulis oleh editor) 